\title{
特集 マンションの新たな課題と管理のありかた【論説】
}

\section{管理組合の目的からみる管理組合の権能とこれにかかる提案 \\ 一マンション標準管理規約改正を題材に}

Authority of the condominium management association and proposal to which it relates

Yu TOMITA : TMI associates, Attorney

\section{1 はじめに}

マンション標準管理規約の改正が検討されてい る。その内容は, (1)外部専門家が管理者, 理事長, 監 事等の組合役員としてマンションの管理に関与す る制度の導入，(2)マンション改修工事を行う際の 規律の明確化，(3)区分所有者の議決権を区分所有 権の価值割合で配分する制度の導入，(4)コミュニ ティ活動への管理費支出の適正化，5自治会費の 強制徵収を管理組合が行うことの禁止，6管理滞 納に対する法的対処と，幅広い改正となっている。

ここでは, このうち(2)(4)(5)について，マンショ ン標準管理規約でどのように定められているか, その定めは管理組合の目的との関係で問題ないか, 標準管理規約の改正内容は管理組合の目的と適合 するか，標準管理規約改正後も残る問題点とこれ を解消するため標準管理規約再改正内容について 考察する。

\section{2 マンション管理組合の目的と権能}

区分所有法上，マンション建物は，区分所有法 2 条 3 項（以下，「法」という。）の規定する区分 所有の目的となる専有部分と, 法 2 条 4 項の規定 する専有部分以外の建物の部分である共用部分に 区別される。例えば，各住戸の内部は専有部分で あるのに対し，エレベーター，階段，共用廊下は 共用部分となる。
ここで，専有部分は，区分所有者が所有し（法 2 条 3 項), 共用部分は, 区分所有者全員の「共 有」に属する（法11条 1 項）。

共用部分の規律である「共有」に関し，民法 2 条は，憲法13条の「個人の尊重」を受け，「この 法律は，個人の尊厳を旨として解釈しなければな らない」と規定し，民法256条は，「各共有者は， いつでも共有物の分割を請求することができる」 とし，個人の単独所有を原則としている。この点 に関し，内田貴「民法 I」(東京大学出版会，第 2 版補訂版, 平成12年）389頁は, 共有という所有 形態においては，各共有者が他の共有者と意見が 合致しなければ目的物を十分に利用・改良できな いし，自分の単独所有の場合ほどにはその物に利 害を感じないので利用・改良に熱心にはならない とし，共有状態をなるべく早く分割し単独所有に 移行することで，目的物の合理的な利用を図れる としている。

共有者が複数いると目的物の管理には共有者間 の意見の調整のコスト等の取引費用がかかる。そ の反面，共有者は何ら意見調整をしなくとも共有 物をそのまま無償利用することはできる。すると， 各共有者は, 共有者間の意思決定や共有物の管理 に伴う負担を避け，ただ乗り的に共有物を利用し ようとする。そうすると, 共有物の管理が十分に 行われず，結果として，共有物の有効利用を図る ことができなくなる。そこで，共有物については， 
なるべく早く共有状態を解消して単独所有とする ことにより目的物の有効な利用を図ろうとしたも のである。

しかしながら，共用廊下やエレベーター等のマ ンションの共用部分に関しては, マンションが物 理的に分割不可能な建物である以上，これを分割 して各区分所有者の単独利用に供することは考え られない。そうであるから，マンションの共用部 分については, 単独所有に分割する方法で有効利 用を図ることはできず，共有状態が継続すること を前提に，他の区分所有者との意見の調整や意思 決定を円滑にできる仕組みを設けることによりそ の有効利用を図るしかない。

また, マンションの共用部分は, 特定の区分所 有者の利用を排除できず（排除不可能性），かつ, ある区分所有者が利用したからといって他の区分 所有者が利用できなくなるものでもない（非競合 性）ことから，一種の公共財である。そうである から，各区分所有者はなるべく管理に伴う負担を 避けつつ無償で共用部分を利用しようとする（フ リーライド)。そうすると, マンションの共用部 分に関して何ら法規制が設けないと，共用部分の 管理がほとんど行われないことになり，ひいては, マンションのスラム化により，マンション居住者 だけでなく周辺環境に対しても悪影響を与えるこ とになりかねない。

そこで, 区分所有法は, 共有状態の継続を前提 とした共有者間の意見調整にかかる取引費用の問 題, 公共財としての性格からくるフリーライドの 問題といった市場の失敗に対処するため, 自由主 義的な民法の共有の規定を公共の福祉（憲法13条， 民法 1 条 1 項）の観点から修正し, 強制加入団体 としてのマンション管理組合を定め, 管理組合に よる管理費の徵収，共用部分の管理等の定めを設 けた。

このように，区分所有法は，マンションが物理
的に分割不可能であることを前提に，共有物の管 理を円滑に行うために個人の自由を制限するもの である。そうであるから，自由の制限も共有物の 管理の円滑という目的達成の限度で是認される。

法 3 条は，管理組合に関し，「区分所有者は, 全員で，建物並びにその敷地及び附属施設の管理 を行うための団体を構成し」と規定している。

管理組合の目的及び権能は，この「建物並びに その敷地及び附属施設の管理」に限定されるが, この規定は，共有物の管理の円滑の観点から理解 される。

\section{3 管理組合の目的との関係でみる改修工 事の規律と標準管理規約改正の問題点}

\section{（1）マンション標準管理規約改正における改修工 事の規律}

区分所有法上，共用部分は，区分所有者全員の 共有に属する（法11条 1 項）から，民法の建前か らすると,「変更」は全員の同意により行い（民 法251条)，「管理」は過半数により行い（民法252 条),「保存行為」は各自が行える（民法 252 条た だし書）はずである。しかし，区分所有法は，共 用部分の「変更」は区分所有者及び議決権の各 4 分の 3 以上の多数決とし (法17条 1 項), 共用部 分の「変更」について，より意思決定が成立しゃ すい方向への修正を行っている。

そして, 改正後の標準管理規約 21 条 3 項は, 共 用部分の「保存行為」に関し，理事長（区分所有 法の「管理者」）の承認を要するとしている。こ れは，法18条ただし書で区分所有者が単独で共用 部分の保存行為を行うことができるとしていたの を, 法18条 2 項の「別段の定め」を行い, 管理組 合の理事長の承認がなければできなくしたもので ある。

今回の標準管理規約の改正は，共用部分の改修 に関して，民法の規律からすると区分所有者が単

福井秀夫「マンション建替え・管理の法と経済分析」自治研究84巻12号（平成20年）38頁は，区分所有法は土地の最有 効使用の実現を迅速・安価・確実，かつ臨機応変に支援するため, 当事者の取り決めに対する補完的な政府関与により 取引費用の減少を図っているものとしている。 
独でできるはずの保存行為も含め原則として管理 組合によることを明確化し，管理組合による共用 部分の管理を一歩進めたものである。

管理組合に関しては，法 3 条が「区分所有者は, 全員で，建物並びにその敷地及び附属施設の管理 を行うための団体を構成」と規定していることか らして，共用部分の改修は管理組合の業務と考え られる。また，実際上，共用部分の改修は大規模 かつ複数の区分所有者に影響し管理組合の主導で 進める必要がある。そうであるから，かかる規律 改正は望ましいものである。

\section{（2）共用部分の修繥者とその瑕疵の損害賠償請求 権者の乘離という問題}

(1)で述べたとおり，改正後のマンション標準管 理規約では，共用部分の改修工事は，保存行為も 含め，原則として管理組合が行う建前となる。

そうであるから，共用部分の改修工事の費用は， 保存行為も含め，原則として管理組合が負担する。

この点, 改修工事の原資は, 個々の区分所有者 が支払う修繕積立金であり，管理組合は，標準管 理規約 25 条により修繥積立金の支払いを受ける。 そうであるから，通常であれば管理組合が改修工 事を行うに際し特に問題は生じない。

しかしながら, 建物の完成当時から建物の耐震 性に不足があったマンションのように，マンショ ンの販売時において, 建物に構造耐力上の瑕疵が あった場合, マンション販売業者と個々の区分所 有者が区分所有権の売買の売主と買主であり，管 理組合は当事者でない。

そのため, 管理組合による共用部分の修繥工事 の原資が区分所有者による損害賠償請求権の行使 に従属せざるをえない局面が生じる。マンション の完成当時からの耐震性不足については，平成17 年の耐震偽装事件, 平成 27 年の杭打ちデー夕偽装 事件に見られるように，今後とも耐震性が不足し ているマンションが建築され，これに伴う大規模 修繥工事や建替えを要する事例が生ずることも予 想されていることから，軽視してはならない。
この点, 確かに, 法26条 2 項は, 「管理者は, その職務に関し，区分所有者を代理する。」，「共 用部分等について生じた損害賠償金‥の請求及び 受領についても, 同様とする」, と規定し, ここ で，「その職務」とは，共用部分の管理（法26条 1 項）を指すから，管理組合の管理者は，共用部 分の管理事務を行うについて，区分所有者を代理 しており，管理者は共用部分の瑕疪に関する損害 賠償請求及び損害賠償金の受領について，法律に 基づいて区分所有者を代理している。そして，組 合の管理者は，法 26 条 4 項により，規約又は集会 の決議により, 訴訟の当事者となることができる (任意的訴訟担当)。

そうであるから, マンションに構造上の瑕疪が あった場合, マンション管理組合の管理者はマン ション販売業者と交涉し，これにかかる補償金を 受け取ることができる。

しかしながら，組合の管理者は，あくまで各区 分所有者の販売者に対する売買契約に基づく瑕疵 担保責任に基づく損害賠償請求権を代理して行使 する。

そこで，区分所有者のうち，区分所有者からの 転得者は, 販売業者との間で売買契約が存在しな いため，販売業者に対する損害賠償請求権を有し ていないという問題が生ずる。

そして，层疵担保責任に基づく損害賠償金は区 分所有者に可分的に帰属し，共用部分についての 区分所有者の共用持分は，「専有部分の床面積の 割合による」(法14条 1 項) から，組合の管理者か らの損害賠償請求は, 「全損害額 $\times$ 販売業者から 直接購入した区分所有者の床面積 / 全区分所有者 の床面積」により求められる損害の限度で損害賠 償請求をすることができるにとどまる。

そして，確かに，この場合において，区分所有 権が売却されている場合，前区分所有者に連絡し， 組合の管理者または現在の区分所有者が前区分所 有者から瑕疪担保責任に基づく損害賠償請求権の 債権譲渡を受け，管理者が前区分所有者の損害賠 償請求権を行使することが考えられる。しかしな 
がら，実際には，前区分所有者の所在が知れない 場合や，前区分所有者に損害賠償請求権の債権譲 渡を求めても同人がこれに応じない場合がある。

そうだとすると，区分所有者の 2 割が当初の区 分所有者と異なる事態を想定すると，管理者は, 訴訟において全損害の 8 割までは填補されるが, 残りの 2 割については填補されず, 結果として, 確定判決により損害賠償請求が認められても予定 していた改修工事を行えない事態が生ずる。

このように，改正後の標準管理規約において， 共用部分の改修工事を保存工事も含め第一次的に 管理組合に委ねたのは適切であったとしても，こ の実効性を担保するための制度として，共用部分 に瑕疵があった場合の損害賠償請求権を管理組合 に留保する制度がないため，管理組合による共用 部分の改修工事を行えない事態が想定される。

\section{（3）標準管理規約改正の問題点とその改善策}

以上のような問題は, 現在の標準管理規約 21 条 において, 区分所有権の売買契約における瑕疪担 保責任に基づく損害賠償請求権等の請求権に関し, 特段の規定を設けず民法の規律に委ねたことに基 づいている。

しかしながら，標準管理規約上，共用部分の瑕 疵の補修に関しては, 保存行為も含め第一次的に 管理組合が行うこととなる以上，損害賠償請求権 も管理組合の管理者に集中させるのが望ましい。

この点, 確かに, 共用部分の持分を区分所有者 が有していることからすると区分所有者の瑕疪担 保責任に基づく損害賠償請求権を奪うことの正当 性が問われる。しかし, 区分所有者が仮に判決に より補修費用相当額の損害賠償を受けたとしても， 区分所有者はこの補修費用でマンション建物の共 用部分を補修する権能を有していないのであるか ら，区分所有者の瑕疵担保責任に基づく損害賠償 請求権を奪うことは問題ないと思われる。

また，各区分所有者は，組合の理事長が承認し
た場合，共用部分の保存行為を行うことができる ため, 共用部分の保存行為にかかる損害賠償請求 権の扱いをどのようにするかが問題となるも，保 存行為としては軽微な改修工事が想定されている のみであるから，共用部分に関する損害賠償権を 一元的に管理組合に集中させても問題ないと思わ れる。

そこで，改正後の標準管理規約21条の建前と平 大を合わせる形で，同条に，「各区分所有者は, 区分所有権を購入した時点において, 売買契約に おける区分所有権の販売業者に対する瑕疪担保責 任に基づく損害賠償請求権その他の権利を管理組 合の理事長に無償にて譲渡する」と定めた条項を 追加し, 組合の管理者が損害賠償請求権を満額行 使できることとすべきである。このような定めを 設けることは，管理組合による共用部分の管理の 円滑という観点からも是認される。

なお，区分所有者の瑕疪担保責任に基づく損害 賠償請求権に関しては, 売買契約上の瑕疪担保責 任に関する損害賠償請求権が転売とともに転得者 に移転されるべきとの議論がある2。しかし，区 分所有権の売買契約において損害賠償請求権の譲 渡特約がない場合にそのような特約を認めること はできない。また，マンションの共用部分に関し ては管理組合による改修しか考えられないため, 瑕疵担保責任に基づく損害賠償請求権を転得者に 移転させるよりも，標準管理規約上管理組合の管 理者に原始的に帰属させるほうが合理的である。

\section{4 管理組合の目的との関係でみる管理組 合による自治会費徵収, 地域コミュニ ティ活動}

\section{（1）管理組合の目的との関係でみる現行標準管理} 規約のコミュニティ条項の問題点

現行の標準管理規約 32 条 15 号においては，管理組 合の業務として，「地域コミュニティにも配慮し た居住者間のコミュニティ形成」があげられてお 
り，同規約 27 条 10 号においては，管理費の使途と

して，「地域コミュニティにも配慮した居住者間 のコミュニティ形成に要する費用」があげられて いる。

この点, 区分所有法は, マンションが物理的に 分割不可能であることを前提に，共有物の管理を 円滑に行う観点から民法の自由主義的な共有の規 定を修正し個人の自由を制限するものである。そ うであるから，個人の自由の制限は共有物の管理 の円滑という目的達成の限度で是認される。

そして，法 3 条が，管理組合に関し「区分所有 者は，全員で，建物並びにその敷地及び附属施設 の管理を行うための団体を構成し」と規定してい るのもかかる趣旨から理解される。

そうだとすると，現行の標準管理規約の「居住 者間のコミュニティ形成」との文言は, 共有物の 管理の円滑という目的から逸脱するものといわざ るをえず，これを理由に個人の自由を制限するこ とはできない。その意味で, 現行の標準管理規約 の規定は，区分所有法 3 条に反しており，整合し ていないといわざるをえない。

\section{（2）管理組合の目的との関係でみる自治会費の徵 収の問題点}

かかる現行の標準管理規約の規定の存在から， 管理費から自治会費の支払いが行われたり，管理 組合により自治会費の強制徴収が行われたりして, トラブルが生じる事態が認められた。

この点, 裁判例をみると ${ }^{3}$, 東京簡判平成19年 8 月 7 日 $^{4}$ は町内会費の徴収は法 3 条の管理組合 の目的外の事項であるから，管理組合において町 内会費の徴収を多数決で決定し, 規約等で定めて もその拘束力はないとして, 管理規約の町内会費 徵収の規定を無効とし, 町内会費の返還を命じて
いる。東京高判平成19年 9 月 20 日判例集未登載は, 管理組合が管理費からコミュニティ形成業務の業 務委託費用名目で区分所有者 1 名あたり200円を 自治会に対し支払っていたことについて，実質的 には自治会費の支払いであり，自治会を脱退した 者との関係では自治会費相当分は管理組合の不当 利得が成立するとしている。

これに対し，東京高判平成24年 5 月 24 日 $^{5}$ は, 管理組合が管理費から町内会費を支出する旨の定 時総会決議をしたところ, 区分所有者が管理組合 の目的の範囲外としてこの決議の無効を主張した 事案であるが，管理規約に町内会への加入義務や 町内会費負担義務が記載されており町内会との良 好な関係を築くことも管理組合の業務内容に含ま れるとして，決議を有効としている。

法 3 条が，管理組合に関し建物並びにその敷地 及び附属施設の管理を行うための区分所有者全員 で構成される強制加入団体である旨を規定してい る趣旨は，共有物の管理の円滑という目的の限度 で個人の自由の制限を是認するものである。

かかる趣旨からすると, 管理費の支出は, 仮に コミュニティ活動といいうるものであったとして も，あくまで共有物の円滑な管理の観点から，マ ンションやその周辺の美化・清掃, 景観形成, 防 犯・防災, 生活ルールの調整等, これによりマン ションの資産価值の向上が見込める活動への支出 に限られる。

そうであるから，地縁団体である町内会や自治 会の会費の支払いを管理費から行ったり，管理規 約で自治会費の支払いを定め, 強制徵収したりす ることは，管理組合の目的の範囲外であるだけで なく，そもそも区分所有法の立法目的を逸脱して 個人の自由を制限するものである。

なお，法 3 条の「管理」に関し，建物・敷地等

3 なお，最判平成17年 4 月26日判時1897号10頁は，自治会が自治会からの退会の意思表示をした県営賃貸住宅の賃借人に 対し自治会費の支払いを求めた事案において，自治会から退会を申し入れた後は自治会費の支払い義務がないことを判 示しているが, かかる判決は管理組合による共有物の管理の問題とは無関係である。

4 東京簡判平成19年 8 月 7 日 LEX/DB 文献番号 28132223

5 東京高判平成 24 年 5 月 24 日 LEX/DB 文献番号 25503340 
の物理的管理のみならず，コミュニティの管理も 含むとする見解もある。

しかしながら，2で述べたとおり，憲法13条， 民法 2 条が個人の尊厳を定め, 民法が自由主義的 共有規定を定めているところ，区分所有法が共有 物の管理の円滑の限度で民法の規律を修正してい ることを鑑みるに，区分所有法の中でコミュニ ティの管理まで含めるのは困難であろう。

改正標準管理規約は, 改正前の標準管理規約 32 条15号が管理組合の業務として,「地域コミュニ ティにも配慮した居住者間のコミュニティ形成」 が定めていた点，同規約 27 条 10 号において，管理 費の使途として，「地域コミュニティにも配慮し た居住者間のコミュニティ形成に要する費用」を 定めていた点を削除し，管理費から自治会費を支 出したり，自治会費の強制徵収をしたりすること ができないことを明確化した。かかる改正は, 法 3 条の目的に適合する。

そして, 改正標準管理規約 32 条 12 号が管理組合 によるコミュニティ活動に類する活動として,「マ ンション及び周辺の風紀, 秩序及び安全の維持, 防災並びに居住環境の維持及び向上に関する業
務」に限定したことは，管理組合の目的と整合す る。

\section{5 まとめ}

本稿では，標準管理規約の改正の改修工事に関 する規律，コミュニティ活動に関する規律につい て，管理組合の目的との関係で考察した。どちら においても管理組合の目的に適合する改正が予定 されている。

もっとも，改修工事に関しては，区分所有者が 区分所有権を売却した場合，売却された持分相当 額に関し管理組合が区分所有者の瑕疪担保責任に 基づく損害賠償請求権を行使できなくなるという 問題がある。

そこで，管理組合による共用部分の改修を実効 的なものにしていくためには，標準管理規約上， 各区分所有者の区分所有権販売業者に対する瑕疵 担保責任に基づく損害賠償請求権その他の請求権 を原始的に管理組合の理事長に無償譲渡する旨の 定めを追加する必要がある。

以上 